\title{
The Islamic Environmentalism in Eco-Pesantren Initiatives: Integrating the Sustainable Development Values in Islamic Boarding School
}

\author{
Sarah Anabarja \& Ahmad Safril Mubah
}

Sarah Anabarja

$\begin{array}{lrll}\text { Affiliation } & : & \text { National } & \text { Chengchi } \\ & \text { University } & \\ \text { City } & : & \text { Taipei } \\ \text { Country } \quad: & \text { Taiwan } \\ \text { Email } & \\ \text { Sarah.anb86@gmail.com } & \end{array}$

Ahmad Safril Mubah

Affiliation $\quad:$ Airlangga Universty
City $\quad:$ Surabaya
Country $\quad:$ Indonesia
Email $\quad:$ fisip.unair.ac.id

History

$\begin{array}{lll}\text { Submission } & : & \text { 23 May } 2021 \\ \text { Review } & : & \text { 18 June } 2021 \\ \text { Completed } & & \\ \text { Accepted } & : & \text { 30 June } 2021 \\ \text { Available } & : & \text { 1 July } 2021 \\ \text { Online } & & \end{array}$

DOI :

10.51413/jisea.Vol2.Iss1.2021.75 - 90

\section{Copyright}

This is an open access article distributed under the term of the creative commons attribution 4.0 international licence

\begin{abstract}
The potential of Islamic environmentalism initiatives has been emerging in Indonesian Muslim society. The inclusion of sustainable development ideas into Islamic values has raised an increasing initiative of 'Eco-Pesantren'. Following the numerous programs relating to Sustainable Development Goals (SDGs) in the country, the 'Eco-Pesantren' undertake the ideas by introducing environmental sustainability in their curriculum. This initiative is widely popular after some Islamic boarding schools or 'pesantren' in Java Island have successfully performed the value of sustainable development in their learning process. It is evident that sustainable development ideas are not the opposite of Islamic values, and the Islamic way of life can contribute to the environmental vision of Sustainable Development Goals (SDGs). This article analyses the practice of sustainable development from an Islamic point of view by focusing particularly on environmental issues. To describe the 'EcoPesantren' programs, this article is divided into three sections. First, introducing sustainable development from Islamic perspectives. Second, portraying the growth of Islamic environmentalism in Indonesia and 'Eco-Pesantren' initiatives and the challenges faced by those initiatives. Finally, the conclusion of this study.

Key Words: Sustainable development, Ecopesantren, Islamic environmentalism, Education
\end{abstract}

\section{Cite this article :}

Anabarja, S., \& Mubah, A. S. (2021). The Islamic Environmentalism in Eco-Pesantren Initiatives: Integrating the Sustainable Development Values in Islamic Boarding School. Journal of International Studies on Energy Affairs, 75-90. https://doi.org/10.51413/jisea.Vol2.Iss1.2021.75 - 90

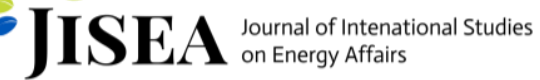




\section{INTRODUCTION}

The growth of Islamic environmentalism is inevitable in Indonesia. It is believed that the value of sustainable development and environmentalism is an integral part of the Islamic basic value of life. One of the efforts is showed by the initiatives of many Islamic Boarding schools or 'pesantren' to integrate their education system towards the value of sustainable development, especially in terms of environmental sustainability. Several 'Eco-Pesantren' in Java are developing their education system to perform sustainable development values within their members of teachers as well as the students. Islamic religious thinkers use Islamic approaches to protect the environment and give examples of how Muslims, particularly in Indonesia, are contributing to this effort through education, legal frameworks, and conservation practices. This article describes the program of 'Eco-Pesantren' and the way they practice sustainable development values from an Islamic point of view.

Islamic environmentalism and the raising awareness of environmentalism in Islamic society in Indonesia is not a new case. In this country where there are at least six religions are being recognized, Indonesian religious societies were already integrated their belief system towards the sustainability of their environment. Many cases of religious activism are related to environmental projects. These are coming from Islamic societies which become the majority in Indonesia, as well as other religious societies such as; Buddhist, Christian, Catholic, Hindu, and Kong hu cu (Confucianism). This trend of religious environmentalism was seen by Pederseen (1995 in Aoki 2016) as part of the counterculture trend of capitalism.

As one of the developing countries, Indonesia is at the same time also facing its problem of environmental danger. Despite the growing number of deforestation and industrial waste problems, environmental awareness is also increasing. Most of the programs are raised not only 
by government bodies like the Department of Forestry and Environment, but also many NGOs, student associations, as well as educational institutions. These stakeholders are trying to realize sustainable development by helping Indonesian to live in a respected, protected, and conserved environment. Most of them are working to preserve and enhance the quality of the natural environment, preserving renewable resources, conserving and protecting water resources. However, the approaches of structural 'top-down' pattern of the environmental program were doubtfully effective due to its applications in the fields. The study of Mangunjaya and McKay (2012) notes that the efforts to protect or preserve Indonesia's natural environment require a strong and innovative approach. They argue that many conventional attempts corresponded to government policies have, in general, not socially inclusive (Mangunjaya \& McKay 2012). These policies may give the impression that local populations cannot constructively engage in the process, particularly when the establishment of conservation areas requires the alteration of traditional rights.

By using the literature study and picking up several cases of 'EcoPesantren' in Java, this article explores the potential institution of Islamic Boarding School to integrate to recent development agenda, especially environmental sustainability in the biggest Muslim country like Indonesia. Continuing the previous study of Aoki (2016) as well as Fawaid (2016) in the similar topic, this study gives an additional case which includes the feature of modern management system to incorporate the value of Islamic environmentalism in Indonesia. Not only the centralized role of Kyai, but also the modern Islamic Boarding School that managed its 'eco-pesantren' system by using modern approach. Henceforth, this article relies on its discussion to be more focused on the potential and effects of the 'Eco-Pesantren' system by reviewing theoretical and empirical studies that existed. It also provides analysis that suggests that 'Eco-Pesantren' can play an important role in meeting one of the Sustainable Development Goals (SDGs) of environmental sustainability. The usage of a theoretical framework on 
Alternative Development by Pieterse (1998), Social Capital by Putnam (1993) and Fukuyama (2001) Maqashid Al-Sharia (Al-Ghazali), and set of 'Eco-Pesantren' initiatives particularly in Java Indonesia are employed in this paper. By those stances of purpose, this article builds its set of arguments based on two questions; (1) what programs do 'EcoPesantren' initiatives incorporate Islamic environmentalism in Indonesia? And (2) in what way is Islamic environmentalism be able to be integrated into the value and practice of sustainable development?

\section{METHOD}

This article applies literature study, qualitative interview, and observation to collect data. A literature study is carried out to gather the written information from books, journals, working papers, magazines, newspapers, research reports, official documents, etc. These written resources are collected from libraries and internet resources. It also employs the series of observations through the practice of 'EcoPesantren' conducted by related Islamic boarding schools in Java with the interviews with the staff and prominent people. The interviews are conducted in Bahasa Indonesia and Jawa to help understand the unspoken culture of interviewing the Muslims in the Javanese culture context. All collected data are being analyzed through qualitative analysis. As Babbie (2013) suggests qualitative analysis is "the nonnumerical examination and interpretation of observations, to discover underlying meanings and patterns of relationships." Primary data from interviews and observations will confirm preliminary findings in secondary data from the literature study. The data classification specifically will be set to make a pattern of relationships among particular data to draw general meanings. Based on this generalization, this article is being concluded. 


\section{RESULT AND DISCUSSION}

\section{Islamic Environmentalism}

The study of environmental change in the framework of sustainable development and religion is not a new thing. Bergmann in Tomalin (2015) argues that this is not an odd relation of religion and environmental issues, remembering that the religious narrative always includes the origin and the future of life as how the basic concept of sustainable development. The basic description of sustainable development according to the Burtland Report (1987) is to ensure the ability of future generations to meet their own needs in the process of fulfilling the needs of the present. As the basic strategy to pursue Sustainable development is to make sure that the dimension of society, environment, and culture, as well as economy, will not be separated. Hence to relate the religion as part of the cultural system as Geertz (1973) mentioned will lead us to another further discussion on the relations of environmental change and human practices as well as their tradition.

In further discussion of the religious discourse, there was a significant point in the Asisi declarations. This declaration was initiate by at least five major religions in response to an ecological issue and climate change. The discussions were held by the World Wide Fund for Nature (WWF) and International Consultancy on Religion, Education, and Culture (ICOREC) in Asisi, Italy. The meeting suggests ways for religious teachings to support the ethical way to limit the exploitation of natural resources. This was one of the examples which Tomalin (2015) mentioned about "the greening of religion", or Pedersen (1995 in Aoki 2016) referred to as "religious environmentalist paradigm". Those concepts have marked the emergence of religious environmentalism which occurred as a response to climate change.

In Islamic religiosity, a similar process of discourse also emerged as another religious tradition to cope with the threat of environmental change. Internationally, an initiation of exchange approach called 
"theoecology" among the scientists, activists, and religious leaders was started a decade ago by the Islamic Foundation for Ecology and Environmental Sciences (www.ifees.org.uk). The founder was one of the Islamic scholars, Fazlun Khalid who believes that environmental teaching is inherent to Islam. Muslim ethicists and legal thinkers have concluded that Islam puts forward conservation of the environment as one of the highest goals of Islamic law (sharia). This may be recognized through the fundamental legal and ethical theory which is guiding criteria for the "purposes of the law" (Maqashid Al-Sharia). The principles of Islamic tradition and practices towards the environment, which include the goals for protecting the faith, life, progeny, intellect, and wealth (Al-Ghazali 2011). Maqashid Al-Sharia is the fundamental base for any material matters to be able to adopt in a Muslim society, including SDGs ${ }^{1}$. According to Kamali (2008), Maqashid Al-Sharia serves as the purpose of all norms and rules implemented from the Islamic point of view (sharia). Maqashid Al-Sharia is built on a basic assumption that the jurisprudence is all at the hand of God the creator, with Al-Qur'an and Sunnah which built on goal attainment of benefits, not just for the individual but also social. Thus, the derivative sources under the main sources of the Islamic ontology should also refer to the achievement of individual and community of Islamic trends broadly, not just using the approach of classical Fiqh ${ }^{2}$ (Ebrahim et al., 2016). Linked with Ebrahim's et.al. (2016) argument that economic and social development today needs to follow a dynamic based on ijtihad 3 in Islamic trends, not just classical Fiqh, is very relevant to the case of

\footnotetext{
${ }^{1}$ In practice, many Islamic scholars who try to build a framework of Maqashid Al-Sharia. The most famous one was the concept offered by Al-Ghazali, Al-Shatibi, and Ibn Qayyim. Al-Ghazali formulate Maqahid AlSharia into five aspects and focus on fulfilling it. The aspect are; Al-Din (religion), Al-Nafs (life), Al-Aql (intellectual), Al-Nasl (progeny) and Al-Mal (wealth/property). Al-Ghazali (2011) stated that the Maqashid Al-Sharia is about the fulfillment of these five aspects of the above with the religious aspects as aspects with highest priority. In addition to Al-Ghazali's categorization, Ibn Qayyim argue that the goal of Maqashid AlSharia is the creation of justice for communities in achieving social welfare. Thus, when SDGs are not in conflict with any of Islamic legal formal then SDGs, especially environmental sustainability are acceptable to be integrated with Islamic qur'anic teaching by using Maqashid Al-Sharia.

${ }^{2}$ The theory or philosophy of Islamic law, based on the teachings of the Qur'an and the traditions of the Prophet (en.oxforddictionaries.com)

3 Islamic legal term meaning "independent reasoning," as opposed to taqlid (imitation). (http://www.oxfordislamicstudies.com)
} 
SDGs. In addition to compliance with the purposes of Sharia, it also encourages the creation of a climate of dynamic and innovative development on the conservation of the environment in general.

As one of the most major number of Muslims in the world, Indonesia is also one of the countries which develop its fundamental thought of Islamic environmentalism. From the guidebook released by the Ministry of Environment and Forestry (Kementrian Lingkungan Hidup dan Kehutanan, MENLHK) it shows the relations between human and nature through the Islamic perspective. The concept of "khalifa" (stewardship) which refers to human and "keseimbangan" (balance) to explain how human as part of nature should balance the ecological system. Before this, the former president of the Indonesian Ulema Council (Majelis Ulama Indonesia, MUI) Dr. Ali Yafie, explained that the relations between humans and nature according to Islamic teachings are divide into three forms; (1) destroyer, (2) developer, (3) manager (Aoki 2016). He stressed that to keep the balance of nature, humans should take responsibility to manage nature. This is similar to the meaning of "khalifa" which means stewardship. In the field of social movement, Nahdlatul Ulama (NU) 4 as one of the largest Muslim Organizations in Indonesia also took part in the discourse of Islamic environmentalism. In their $29^{\text {th }}$ Congress in 1994, most of them stated that environmental problems are also a theological issue (Pengurus Besar Nahdlatul Ulama 1996 in Aoki 2016). They argue that Allah created humans as "khalifa" whose supposed to be the responsible ones to take care of nature. Consequently, through the propagation to improve thought and behavior following Sharia, the human must aware of the upcoming problems faced by environmental change. Aoki (2016) notes that since the 1990s the environmental approach towards more practical efforts emerged in Indonesia.

\footnotetext{
${ }^{4}$ Nahdlatul Ulama (NU) is the biggest Islamic FBOs in Indonesia. In total there are 79.04 million muslims affiliated with it. Founded by two most respected muslim clerics from Jombang, NU was founded in 1926 in Surabaya. Up until now, NU considered as the most influenced Islamic FBO in Indonesia. http://www.nu.or.id
} 


\section{Islamic Boarding School and Its 'Eco-Pesantren' Initiatives}

The initiatives of educating the value of sustainable development through Islamic environmentalism includes several values of Qur'anic perspectives as its foundation. According to the study of Mangunjaya \& McKay (2012), those values include; Tawhid5, Khalq ${ }^{6}$, Mizan $^{7}$, Ihsan $^{8}$, Fasad $^{9}$, and Khalifa ${ }^{10}$. The goal of delivering such values is to lit more familiar discussions on what may be intended by the Qur'anic verses regarding the environmental themes along with actual examples found in realities. Working as the idea of Islamic Environmentalism as a principle belief, Maqashid Al-Sharia can be implemented well in Indonesia and integrate with the SDGs program by working together with many agents especially the Islamic Boarding School and its 'EcoPesantren' initiatives. Eco-Pesantren initiative, according to Mangunjaya and McKay (2012) refers to the Pesantren education system as well as its cultures to indoctrinates the Islamic environmentalism values mentioned above.

Pesantren or Islamic Boarding School are one of the basic and popular religious institutions worked in the education system. The education system of Pesantren used the holistic approach of basic everyday life with the center of its system usually lead by Kyai (religious leaders). As Aoki (2016) wrote in his research, Pesantren is a vital education institution that prepares Muslim youths to deal with both religious and

\footnotetext{
${ }^{5}$ Tawhid related to the "Oneness" nature of the Creator, His creation and the importance of its conservation.

${ }^{6}$ Khalq is the way Qur'an deals with matters relating to the environment and conservation through verses relating to "khalq" (creation).

${ }^{7}$ Mizan is the principle of balance and how the earth remaining in a stable balance is a step toward conserving the environment.

${ }^{8}$ Ihsan is the knowledge that Allah created humankind in a state of goodness and understanding our place in fitra

(the Qur'anic term for an original state of nature).

${ }^{9}$ Fasad is knowing the capacity of human species for destructive behavior which leads to the destruction to the environment.

${ }^{10}$ Khalifa is knowing our human responsibilities as guardians of the environment, as expounded in the Qur'an, including our treatment of other sentient beings.
} 
social affairs, including environmental issues. Kyai who leads in Pesantren, are not only served as a religious leader within the Pesantren. He usually also serves as a local informal leader in their society. Thus, their opinion is not only heard by their santri (students) but also influenced the local society among them including the local government.

According to the study of Mangunjaya and McKay (2012) as well as Aoki's (2016) the design of 'Eco-Pesantren' was to use the Islamic indoctrinates through the charismatic leadership of Kyai and also the education holistic education system of Islamic Boarding School. In Pondok Pesantren (PP) Annuqoyyah, they used one of their own tradition of "kompolan" to discuss their environmental problems from the perspectives of Islam (Aoki 2016). This conservative approach was rather using the charismatic power of Kyai to gather local people together with their students. This tradition is similar to many other Pesantren which usually gather people and sit together with the Ulema to discuss and listen to Qur'anic teachings. It is not new, but it has a very strong influence on the traditional community in the rural area. Some Pesantren which had already initiate the program of Islamic environmentalism like PP Daar El Qolam (Tangerang), PP Al Musaddadiyah (Garut), and PP Buntet (Cirebon) (Mangunjaya 2012). Another example taken by the study of Aoki (2016) was located in Central Java called PP At-Tauhid Al-Islamiy, and PP Annuqoyyah in Madura (Fawaid 2016). Another latest example observed by authors is Islamic Boarding School Roushon Fikr in Jombang.

In addition to its conservative approach, many Pesantren during these two decades already develops themselves to includes students more in initiating their environmental program. In PP Annuqoyyah, starting from 2008 there were programs to include the environmental conservation program into the school's activities. Their program was based on student initiatives to be sustainable for a longer period (Fawaid 2016). Their student initiates themselves to implement the Qur'anic teaching on environmental sustainability by went to the public 
dump, collected plastic rubbish and created many kinds of creative handicrafts from such rubbish. They are also involved in the socialization of plastic rubbish in other schools and local people (Fawaid 2016). Their basic idea of these 'Eco-pesantren' initiatives is increasing the student's eco-literacy and lit their eco-pedagogy in the value of environmentalism. In this way also, their initiatives able to literate local people about the dangerous potentials of plastic rubbish and the importance of conservation for the environment.

Another example we took here is the city famous as Kota Santri (City of Students), Jombang. This city, settled by several major and famous Pesantren in Indonesia, like PP Darul Ulum, PP Tambak Beras, PP Tebu Ireng, and many more which are usually affiliated to NU. As we observed in 2019, one of the Islamic Boarding Schools called Roushon Fikr, develop its programs according to Islamic basic understanding of nature. One of their programs is called the "Kebun Sayur Sehat dan Ikan Organik" (Healthy Vegetable Field and Organic Fish). From the interview with Ahmad Didin Sholahudin, one of the founders of Roushon Fikr Foundation, their goals are to fulfill the daily needs of their students, teachers, all board staff which are around 1000 people, and even their surrounding local society in Jombang (Figure 1).
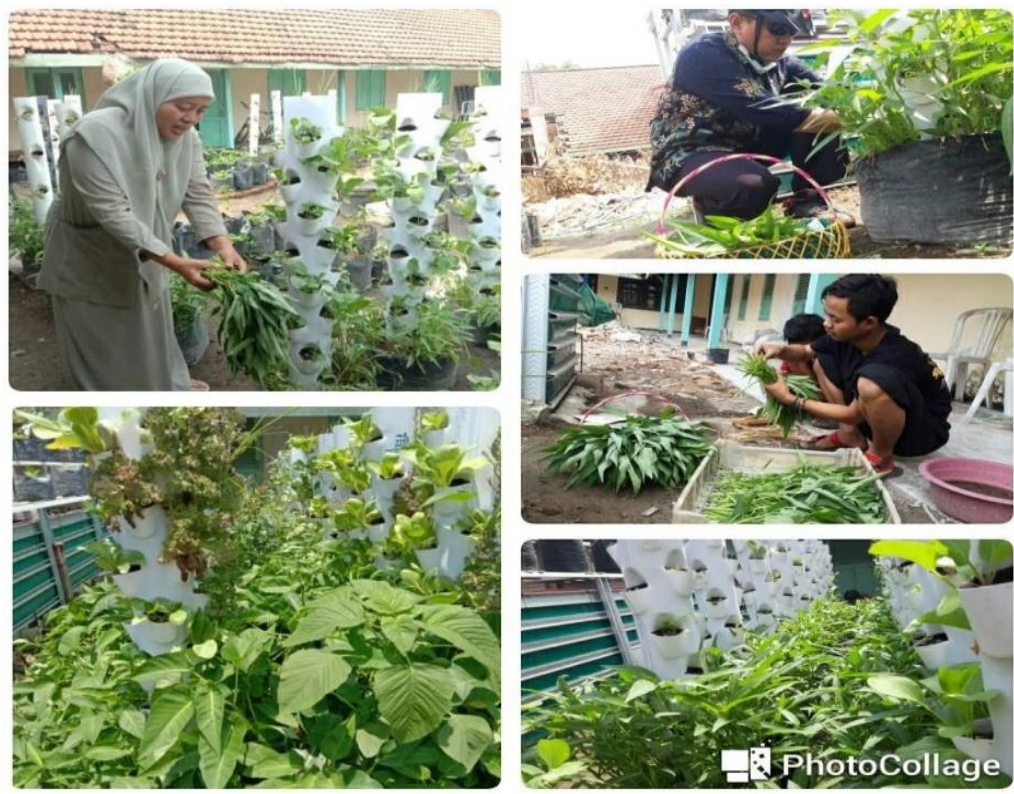

Figure 1 Kebun Sehat Roushon Fikr Jombang Source: Ahmad Didin Sholahudin (2019) 
Located in the middle of Jombang City, Roushon Fikr is different from another Islamic Boarding School in Jombang which usually manages traditionally and centered their activity based on their Kyai. Distinctively, Roushon Fikr which is also affiliated with NU, design their curriculum and program using modern and professional management without undermining the role of their teachers (ustadz). Thus, the program of "Kebun Sayur Sehat" is managed by the special division of organic farming in their foundation. However, this program is unseparated from another activity within their education system. Their targets on this program are; 1 ) producing organic vegetables and fish products ${ }^{11}$, 2) education laboratory for their students and neighboring society in organic and self-sustaining farming, 3) providing place and activity for workshop or training on organic farming for the neighboring people (Sholahudin 2019). Sholahudin (2019) also mentioned that this program is actually one of their effort to sustain their own needs in terms of daily consumption of vegetables and protein without leaving their main purpose on educating the students and their staff about Islamic environmentalism. It can be shown by their way on cultivate the field by using organic compost fertilizer from their daily food waste. In the future, he as one of the founders has a goal to make the whole program can be implemented by the students when they graduated from the school. By this means, the value of sustainability and Islamic environmentalism able to be internalized to the society through their students and staff.

${ }^{11}$ See Picture 2 

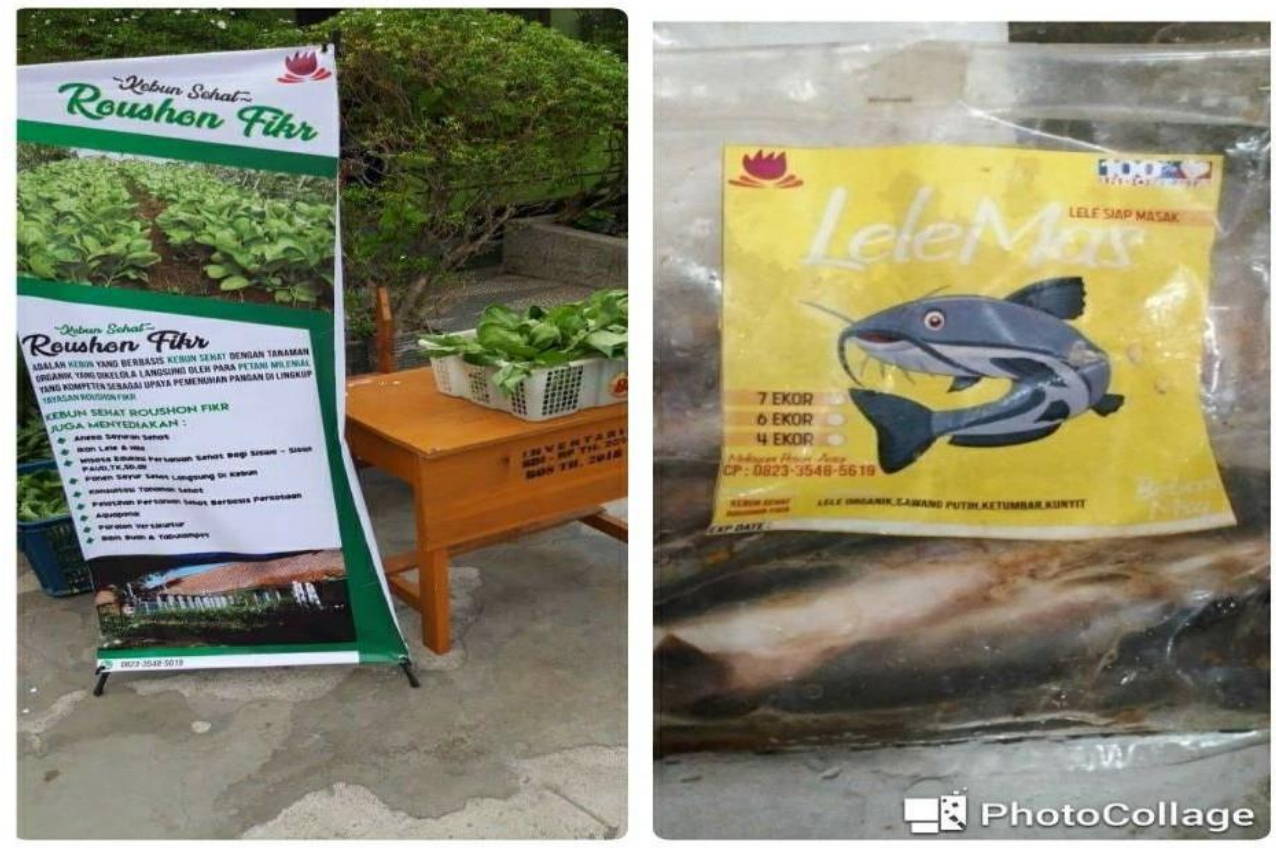

Figure 2 Products of Kebun Sehat Roushon Fikr Jombang Source: Ahmad Didin Sholahudin (2019)

By those cases of "Eco-Pesantrens" and connect it to the social capital by Putnam (1993) and Fukuyama (2001), as well as Maqashid AlSharia by Al-Ghazali (2011) which becomes the main framework among Muslim society in their daily life, we can see how the Islamic value of environmentalism able to be used to pursuing the SDGs. The active role of the teachers and Kyai as well as the management of the Islamic education foundation brought trust from the student's parents and neighboring societies to implement the system by their own will. By this means other stakeholders of SDGs programs like the government, other NGOs, able to work together with these Islamic Boarding Schools for another sustainable development program. But of course, the programs should be in line with the Islamic Value itself since in Indonesia, Muslims are the majority of this country (Figure 3). 


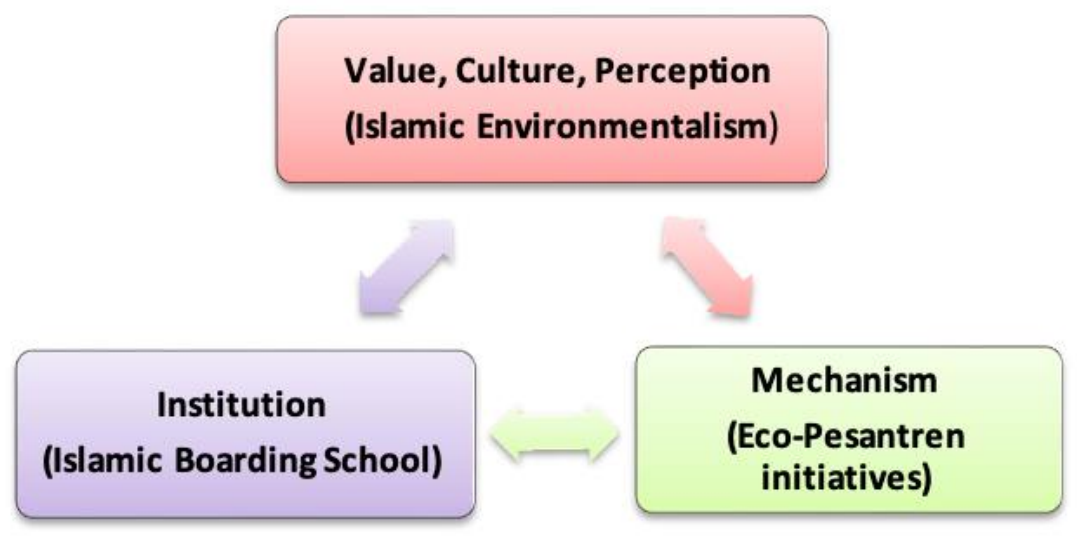

Figure 3 Social Capital Level in the Case of Eco-Pesantren Initiatives

Nonetheless, the good intention of many 'Eco-Pesantren' initiatives on bringing the value of Islamic environmentalism is not always in the same line with sustainable development. As mentioned above, usually the pesantren are managed traditionally and have nothing to do with the SDGs. Although for some Islamic scholars, Islamic environmentalism itself is the value of protecting the life on earth, thus automatically educating the students with Islamic environmentalism value means they are already on the track of pursuing SDGs. This can be seen as one of the major challenges for pursuing SDGs because mapping the implementation of SDGs is different from the Islamic value of environmentalism. Another challenge mentioned by Sholahudin, in the Roushon Fikr case is the continuity of the program. Since they aim to fulfill their own needs of vegetables and protein from the "Kebun Sayur Sehat", means they have to produce the vegetables and fish at least 1000 portions on daily basis. This number is so huge for them hence they have to work together with the neighboring society to keep these needs fulfilled. Even though this is also can be seen as a good thing to keep the value be implemented within the local society. 


\section{CONCLUSIONS}

Islamic Environmentalism is one of the concepts which has marked the emergence of religious environmentalism which occurred as a response to climate change in the Islamic world. In the context of Indonesian Muslim society which mostly is affiliated with NU, the role of pesantren is quite important to use the social capital that existed among them. Thus, the initiative of 'Eco-Pesantren' can be utilized, together with their existing ideology, norms, and institution already in place. In this way, 'Eco-Pesantren'could be part of the agent which able to deliver the process of adaptation in the context of understanding the potential threat of environmental change and the way to mitigate it by living their sustainable life. From the cases brought in this article, it is proved that 'Eco-Pesantren' initiatives towards environmental sustainability can work due to their familiarity with Islamic norms towards nature which deliver through a comprehensive education system of their daily life. Despite the challenges and its limit on the practices of 'Eco-Pesantren' Initiatives, we could see how the eagerness to work towards more sustainable programs that involve a wider community besides its own students or staff. Therefore, future studies might include a larger scope of initiatives that comprise other stakeholders in Indonesian Muslim society. 


\section{REFERENCES}

Al-Ghazali, (2011). Ihya Ulumuddin: Menghidupkan Ilmu Ilmu Agama. (Translated). Bandung: Mirja.

Aoki, Takenobu, (2016). "Islamic NGOs on Environmental Problems in Indonesia" in NGOs in the Muslim World: Faith and Social Services. New York: Routledge

Babbie, Earl, (2013). The Practice of Social Research (13 ${ }^{\text {th }}$ Edition). Belmont: Wadsworth.

Ebrahim, M. S., M. O. Salleh, and M. O. Sheikh, (2016). Institutional status and the underdevelopment of the Muslim world: A juridicio-philosophical critique. Working Paper, Durham University Business School, England, UK.

Fawaid, Achmad, (2016). The Environmental Conservation: An Ecopedagogical Approach Practiced by Pesantren Annuqayah, Madura. DINIKA Academic Journal of Islamic Studies, 1(2) pp 131-142.

Fukuyama, Francis, (2001). Social Capital, Civil Society and Development. Third Worlds Quarterly 22 (1): 7-20

Geertz, Clifford, (1973). "Religion as a Cultural System", in The Interpretation of Cultures. New York: Basic Books.

Interview with Ahmad Didin Sholahudin (2019).

Kamali, Mohammad H., (2008). Maqashid Al-Syariah Made Simple. London: The International Institute of Islamic Thought.

Mangunjaya, Fachruddin \& Mckay, Jeanne, (2012). Reviving an Islamic Approach for Environmental Conservation in Indonesia. World Views Environment Culture Religion. 16. 286-305. 10.1163/15685357-01603006.

Pieterse, J.N., (1998), My paradigm or yours? Alternative development, post development, reflexive development. Development \& Change. 29(20). 343-373. 
Putnam, Robert. (1993). Making Democracy Work: Civic Traditions in Modern Italy. Cambridge, MA: Harvard University Press.

Tomalin, Emma (eds), (2015), "The Routledge Handbook of Religions and Global Development”. New York: Routledge.

United Nations, (1987), "Report of the World Commission on environment and Development: Our Common Future". Retrieved from: https://www.are.admin.ch/are/en/home/media/publications/sustain able-development/brundtland-report.html 